\title{
Bacterial removal in flattened root canals with different tapers of ProDesign Logic
}

\section{single-file system}

\author{
Remoção de bactérias em canais radiculares achatados com diferentes tapers do sistema de lima \\ única ProDesign Logic
}

Eliminación de bacterias en conductos radiculares achatados con diferentes conicidades del sistema de lima único ProDesign Logic

Vanessa Sandini

ORCID: https://orcid.org/0000-0001-9351-7110 São Leopoldo Mandic, Brazil E-mail: vaasandini@yahoo.com.br

Viviane Godoy

ORCID: https://orcid.org/0000-0003-3344-8963 São Leopoldo Mandic, Brazil E-mail: viviane_godoy@hotmail.com

Marina Carvalho Prado

ORCID: https://orcid.org/0000-0002-7116-0402 Universidade Estadual de Campinas, Brazil E-mail: marinaprado@dentistas.com.br

Ricardo Ferreira

ORCID: https://orcid.org/0000-0002-6360-5678 Universidade do Vale do Itajaí, Brazil E-mail: ferreiraendo@gmail.com

Adriana de-Jesus-Soares ORCID: https://orcid.org/0000-0002-8078-1606 Universidade Estadual de Campinas, Brazil E-mail: ajsoares@unicamp.br

Marcos Frozoni

ORCID: https://orcid.org/0000-0001-8001-4063 São Leopoldo Mandic, Brazil

E-mail: marcosfrozoni@gmail.com

\begin{abstract}
Objective: This study evaluated the bacterial removal in flattened root canals after preparation with different tapers of ProDesign Logic instruments. Methodology: Fifty-five mandibular incisors with flattened root canals were contaminated with a pure culture of Enterococcus faecalis ATCC 29212 for 21 days at $37^{\circ} \mathrm{C}$. Root canals preparation was performed using ProDesign Logic and $0.9 \%$ sterile saline solution for irrigation. The specimens were randomly allocated to three experimental groups $(n=15)$ according to the taper of the instrument used: $25.03,25.04$, or 25.06 . Intracanal bacteriological samples were taken before (S1) and after (S2) preparation and the number of colonyforming units per milliliter $(\mathrm{CFU} / \mathrm{mL})$ was calculated. Differences in bacterial counts before and after treatment, within each group, were analyzed by the paired t-test. Groups were compared by ANOVA with a post hoc test. The level of significance was set at $p<0.05$. Results: Mature biofilm formation was confirmed at root canal walls by scanning electron microscopy. Bacterial colonies were significantly reduced in all experimental groups at S2 compared to S1 $(p<0.001)$. No significant difference was observed between groups regarding the percentage of bacterial reduction $(p>0.05)$. Conclusion: Preparation of flattened root canals using ProDesign Logic instruments with tapers of $0.03,0.04$ and 0.06 resulted in similar planktonic and bacterial biofilm reduction. None of the instruments rendered root canals completely free of bacteria.
\end{abstract}

Keywords: Biofilms; Endodontics; Enterococcus faecalis; Root canal preparation.

\section{Resumo}

Objetivo: Este estudo avaliou a remoção bacteriana em canais radiculares achatados após o preparo com diferentes tapers dos instrumentos ProDesign Logic. Metodologia: Cinquenta e cinco incisivos inferiores com canais radiculares achatados foram contaminados com cultura pura de Enterococcus faecalis ATCC 29212 por 21 dias a $37^{\circ} \mathrm{C}$. O preparo dos canais radiculares foi realizado com ProDesign Logic e solução salina estéril 0,9\% para irrigação. Os espécimes foram alocados aleatoriamente em três grupos experimentais $(n=15)$ de acordo com o taper do instrumento utilizado: 25.03, 25.04 ou 25.06. Amostras bacteriológicas intracanais foram coletadas antes (S1) e depois (S2) do preparo e o 
número de unidades formadoras de colônias por mililitro (UFC/mL) foi calculado. As diferenças nas contagens de bactérias antes e depois do tratamento, dentro de cada grupo, foram analisadas pelo teste t pareado. Os grupos foram comparados por ANOVA com um teste post-hoc. O nível de significância foi estabelecido em $p<0,05$. Resultados: Formação de biofilme maduro foi confirmada nas paredes radiculares por microscopia eletrônica de varredura. Colônias bacterianas foram significativamente reduzidas em S2 em comparação com $\mathrm{S} 1(p<0,001)$ em todos os grupos experimentais. Não foi observada diferença entre os grupos quanto ao percentual de redução bacteriana ( $p$ $>0,05)$. Conclusão: O preparo de canais radiculares achatados utilizando-se instrumentos ProDesign Logic com conicidades de 0.03, 0.04 e 0.06 resultou em redução semelhante de bactérias planctônicas e biofilme bacteriano. Nenhum dos instrumentos tornou os canais radiculares completamente livres de bactérias.

Palavras-chave: Biofilmes; Endodontia; Enterococcus faecalis; Preparo de canal radicular.

\section{Resumen}

Objetivo: Este estudio evaluó la eliminación de bacterias en conductos radiculares achatados después de la preparación con diferentes conicidades de los instrumentos ProDesign Logic. Metodología: Cincuenta y cinco incisivos mandibulares con conductos radiculares achatados se contaminaron con un cultivo puro de Enterococcus faecalis ATCC 29212 durante 21 días a $37^{\circ} \mathrm{C}$. La preparación de los conductos radiculares se realizó utilizando ProDesign Logic y solución salina estéril al 0,9\% para irrigación. Las muestras se asignaron aleatoriamente a tres grupos experimentales $(n=15)$ según la conicidad del instrumento utilizado: 25.03, 25.04 o 25.06. Se tomaron muestras bacteriológicas intracanal antes (S1) y después (S2) de la preparación y se calculó el número de unidades formadoras de colonias por mililitro (UFC/mL). Las diferencias en los recuentos bacterianos antes y después del tratamiento, dentro de cada grupo, se analizaron mediante la prueba t pareada. Los grupos se compararon mediante ANOVA con una prueba post hoc. El nivel de significancia se fijó en $p<0,05$. Resultados: Se confirmó la formación de biopelículas maduras en las paredes del conducto radicular mediante el microscopio electrónico de barrido. Las colonias bacterianas se redujeron significativamente en S2 en comparación con S1 en todos los grupos experimentales $(p<0,001)$. No se observaron diferencias significativas entre los grupos con respecto al porcentaje de reducción bacteriana $(p>0,05)$. Conclusión: La preparación de conductos radiculares achatados con instrumentos ProDesign Logic con conicidades de 0.03, 0.04 y 0.06 resultó en una reducción similar de la biopelícula planctónica y bacteriana. Ninguno de los instrumentos dejó los conductos radiculares completamente libres de bacterias.

Palabras clave: Biopelículas; Endodonci; Enterococcus faecalis; Preparación del conducto radicular.

\section{Introduction}

Successful endodontic treatment depends on satisfactory disinfection of contaminated root canals. For this, an adequate chemomechanical preparation and and modeling root canals must be achieved (Siqueira Junior, et al., 2018). Currently, some authors have discussed minimally invasive endodontic procedures in terms of access cavity and root canal shaping (Pérez et al., 2020). Within the context of root canal preparation, minimally invasive endodontic procedures propose the preservation of the root canal walls by selecting instruments with a small taper and good flexibility (Bürklein \& Schäfer, 2015). The approach of reducing root canal enlargement may be interpreted as a conflict with canal disinfection. Although the resistance of contracted endodontic cavities to fractures and the effects of apical enlargement have been frequently investigated, the influence of using instruments with smaller tapers on microbial removal is often not considered (Siqueira Junior, et al., 2018). This is a matter of concern since the elimination or maximum reduction of intracanal bacterial counts is one of the basic principles for successful endodontic therapy.

Root canal preparation with larger tapers, such as 0.06 or 0.08 , allows a significant reduction in Enterococcus faecalis counts compared to smaller tapers (Paraskevopoulou \& Khabbaz, 2016). In contrast, previous studies failed to demonstrate differences in the microbiological reduction of culturable bacteria between different tapers and apical sizes (Moshari, et al., 2015; Silva, et al., 2014). Therefore, the ideal root preparation size for antimicrobial efficacy still needs to be defined.

In the last decades, considerable progress in endodontic instruments, equipment and materials has resulted in simpler, safer and more efficient root canal procedures. For instance, single-file nickel-titanium systems prevent cross-infections and optimize root canal treatment (Azim, et al., 2018a; Azim, et al., 2018b). Single-file systems have gained wide interest and a growing body of evidence regarding physical and microbiological features supports the choice of these instruments for endodontic therapy. Most current single-file systems are available in different tapers and usually exhibit innovative 
manufacturing processes that provide great flexibility such as XP-Endo Shaper (FKG Dentaire, La Chaux-de-Fonds, Switzerland), Reciproc Blue (VDW GmbH, Munich, Germany), and ProDesign Logic (Easy Equipamentos Odontológicos, Belo Horizonte, MG, Brazil) (Azim, et al., 2018b).

ProDesign Logic system was associated with high cyclic and torsional fatigue resistances (Alcalde, et al., 2018) and satisfactory cleaning of root canal debris (Pinto, et al., 2021). This system presents control memory wire alloy and a different hybrid design with a S-shaped cross-section, two cutting edges and inactive points. ProDesign Logic can act in both continuous rotation or reciprocating motion and is available in different tip sizes (25-50) and tapers (.03, .04, .05, or .06). However, the effect in decontamination of root canals is scarce in literature. The aim of this study was to evaluate the removal of planktonic and biofilm bacteria using different tapers of ProDesign Logic system during the preparation of flattened root canals. The null hypothesis was that no difference exists between the tested tapers in reducing root canal bacterial load.

\section{Methodology}

\section{Sample size calculation}

Considering least differences between groups and a standard error of $2 \%$ obtained by ANOVA for three groups (based on a pilot study), a minimum of 14 specimens was required to achieve a test power of $80 \%$ and significance of $5 \%$ in this experimental design.

\section{Specimen selection and initial preparation}

Approval was obtained from the institutional Ethics Committee (Protocol: 14944519.4.0000.5374). Sixty human single-rooted mandibular incisors with a single straight and flattened root canal, extracted for reasons not related to this study, were selected. Preoperative digital radiographs (FIT-T2; Micro Imagem, Indaiatuba, SP, Brazil) were taken in the buccolingual and mesiodistal directions to confirm the presence of a single canal. To ensure the flattened anatomy, only teeth with root canals with a minimum ratio of 2.5:1 between the buccolingual and mesiodistal dimensions, measured at 2, 7 and $12 \mathrm{~mm}$ from de radiographic apex using a digital sliding ruler with a precision of $0.1 \mathrm{~mm}$ (Dental Master DICOM-Plus 1.0.12; Micro Imagem, Indaiatuba, SP, Brazil), were selected (Siqueira Junior, et al., 2010). Teeth with cracks, root fracture, root resorption, calcification, an immature apex and dental caries, and root canals with an initial apical diameter larger than \#15 Flexofile (Dentsply Sirona, Ballaigues, Switzerland) or previous endodontic therapy were excluded. Clinical analysis using a dental operating microscope (Alliance, São Carlos, SP, Brazil) and digital radiographic evaluation confirmed the inclusion and exclusion criteria.

The length of all teeth was standardized at $15 \mathrm{~mm}$ from the apex by sectioning the crown using a low-speed saw with a diamond disc (Isomet 5000 saw; Buehler, Ltd. Lake Bluff, New York, USA) under continuous water irrigation. Next, a \#10 K-file (Dentsply Sirona, Ballaigues, Switzerland) was used to confirm the root length of $15 \mathrm{~mm}$, as well as apical patency when the instrument exceeded $1.0 \mathrm{~mm}$ from the apical foramen. The maximum apical diameter of $0.15 \mathrm{~mm}$ for specimen inclusion was confirmed by fitting a \#15 Flexofile in the apical foramen observed under a dental operating microscope (40X). Root canals were irrigated with $10 \mathrm{~mL}$ of $2.5 \%$ sodium hypochlorite solution $(\mathrm{NaOCl})$ and prepared with a \#15 K-file until the apical foramen was reached. The specimens received intermediary irrigation with $5 \mathrm{~mL}$ distilled water and were filled with 17\% EDTA for 3 minutes. The roots were then washed with $5 \mathrm{~mL}$ distilled water and dried with capillary tips (Ultradent Products, South Jordan, UT, USA) and sterile paper points (Dentsply Sirona, Ballaigues, Switzerland).

\section{Preparation of Enterococcus faecalis suspension and specimen contamination}

Ten $\mu \mathrm{l}$ of a pure Enterococcus faecalis strain (ATCC 29212) was cultured in $5 \mathrm{~mL}$ sterile brain heart infusion broth 
(BHI; Difco, Detroit, MD, USA) for 24h. This suspension was then spread onto BHI agar (KASVI, Curitiba, PR, Brazil) and incubated for $24 \mathrm{~h}$ at $37^{\circ} \mathrm{C}$. After incubation, $5 \mathrm{~mL}$ of the contaminated culture medium was transferred to a glass tube containing $5 \mathrm{~mL}$ of sterile BHI broth, corresponding to the turbidity of a $1.0 \mathrm{McFarland}$ standard.

The apical foramen of the specimens was sealed with a fast set epoxy resin to prevent bacterial leakage and to create a closed-end channel that produces a vapor lock effect (Tay, et al., 2010). Next, the models were filled with sterile BHI suspension and the contaminated culture medium was applied. However, only sterile BHI suspension was used in five specimens as control. These sets were incubated in an anaerobic chamber $\left(10 \% \mathrm{CO}_{2}\right)$ for 21 days at $37^{\circ} \mathrm{C}$. During this period, the culture media were replenished every $48 \mathrm{~h}$ and bacterial viability and purity were confirmed by visual observation of medium turbidity.

\section{Confirmation of bacterial colonization}

From the selected specimens, 10 teeth were chosen as controls. In the positive control group $(n=5)$, the specimens were contaminated but received no root canal treatment. In the negative control group $(n=5)$, the roots were not contaminated and were not submitted to endodontic therapy. The number of colony-forming units per milliliter (CFU/mL) of Enterococcus faecalis was then calculated for the negative and positive control groups. The five specimens of the positive control group were examined by scanning electron microscopy (SEM) to confirm biofilm production. The specimens were removed from the models and fixed in $10 \%$ buffered formalin (Siqueira Junior, et al., 2010). The roots were vertically split into two halves and dehydrated in increasing alcohol concentrations $(40 \%, 50 \%, 70 \%, 80 \%$ and $96 \%)$ for 20 min. The specimens were kept for 24 $\mathrm{h}$ in a desiccator prior to SEM analysis (JSM5600LV; JEOL, Tokyo, Japan). Random areas were selected for evaluation in the cervical, middle and apical regions of the roots, each at magnifications of 50X, 1000X, 5000X, and 10000X.

\section{Root canal treatment and microbial sample collection}

Forty-five contaminated specimens were randomly allocated to three groups $(n=15)$ according to the taper of the ProDesign Logic file (Easy Equipamentos Odontológicos, Belo Horizonte, MG, Brazil) used for preparation: ProDesign Logic 25.03, ProDesign Logic 25.04, or ProDesign Logic 25.06.

Firstly, $1 \mathrm{~mL}$ of sterile saline solution was applied to the specimens and the baseline sample (S1) was taken. Samples were obtained by introducing two sterile paper points (size \#15; Dentsply Sirona, Ballaigues, Switzerland) into the full length of the root canals $(15 \mathrm{~mm})$ and retaining them in position for 1 min. The paper points were then pooled in a sterile polypropylene tube containing $1 \mathrm{~mL}$ of $0.9 \%$ sterile saline solution.

A single operator performed the root canal treatment and all files were single use. The preparation was standardized in all groups by root segment, starting with the cervical region (working length [WL] $=5 \mathrm{~mm}$ ), followed by the middle $(\mathrm{WL}=10$ $\mathrm{mm}$ ) and apical (final WL $=15 \mathrm{~mm}$ ) thirds. Root canal treatment was performed using $15 \mathrm{~mL}$ of $0.9 \%$ sterile saline solution as irrigant, which was delivered with a 27-G x $25 \mathrm{~mm}$ NaviTip (Ultradent Products, South Jordan, UT, USA) by means of a peristaltic pump (LAP-101-3; MS Tecnopon, Piracicaba, SP, Brazil), at a flow rate of $5 \mathrm{~mL} / \mathrm{min}$.

A torque-controlled endodontic motor (Easy Endo SI Básico; Easy Equipamentos Odontológicos, Belo Horizonte, MG, Brazil) was used for setting the ProDesign Logic file according to manufacturer instructions. For this purpose, the singlefile system was set at a speed of $950 \mathrm{rpm}$ and torque of $4 \mathrm{Ncm}$ and activated in the continuous rotation mode. The file was applied in gentle pecking motion with slight apical pressure to advance the instrument through the root length until the apical foramen was reached. If a resistance requiring more apical pressure was detected, the file was removed and cleaned with sterile gauzes soaked in alcohol. During preparation, $5 \mathrm{~mL}$ of $0.9 \%$ saline solution was used in each third of the root canal after the use of the single-file. The irrigant was delivered at the predetermined WL for the cervical, middle and apical segments. 
Once the apical foramen was reached, a final irrigation with $5 \mathrm{~mL}$ saline was performed. A \#15 Hedstroem file (Dentsply Sirona, Ballaigues, Switzerland) was then introduced into the canal to the WL and four circumferential strokes were performed against the buccal, lingual, mesial and distal root walls. This procedure aimed to detach and dislodge biofilm cells adhered to the root canal walls and dentinal debris packed in the buccal and lingual recesses. Root canal contents were then absorbed with two \#25 sterile paper points as previously described.

\section{Quantitative bacterial analysis}

After endodontic treatment of each specimen, the tubes containing the microbial samples were vortexed for 30 seconds. Serial dilutions were prepared from the resulting suspension $\left(10^{-2}, 10^{-4}, 10^{-5}\right.$ and $\left.10^{-6}\right)$ and $0.1-\mathrm{mL}$ aliquots of each dilution were seeded onto Petri dishes containing $\mathrm{BHI}$ agar. The plates were incubated for $24 \mathrm{~h}$ at $37^{\circ} \mathrm{C}$ in $10 \% \mathrm{CO}_{2}$. After this period, the colonies were counted and the number of colony-forming units per milliliter $(\mathrm{CFU} / \mathrm{mL})$ was calculated.

\section{Statistical analysis}

Data distribution was evaluated by the Kolmogorov-Smirnov test. Differences in bacterial counts before and after treatment were analyzed in each group by the paired t-test. ANOVA followed by a Tukey post hoc test was used for comparison between groups at S1 and S2. A level of significance of $p<0.05$ was adopted (SPSS, version 19.0).

\section{Results}

Bacterial contamination with the pure E. faecalis strain was confirmed in the positive control group. No microbial contamination was detected in the negative control group. SEM analysis demonstrated E. faecalis colonization and biofilm-like structures in all root thirds, confirming successful contamination of the dentinal surface in the specimens evaluated (Figure 1). 
Figure 1. Representative SEM images of contamination of the root surface and dentinal tubules with planktonic cells and biofilm-like structures of Enterococcus faecalis in the cervical (1), middle (2), and apical (3) thirds. (a) 5,000X magnification; (b) (input) at magnification $10,000 \mathrm{X}$.
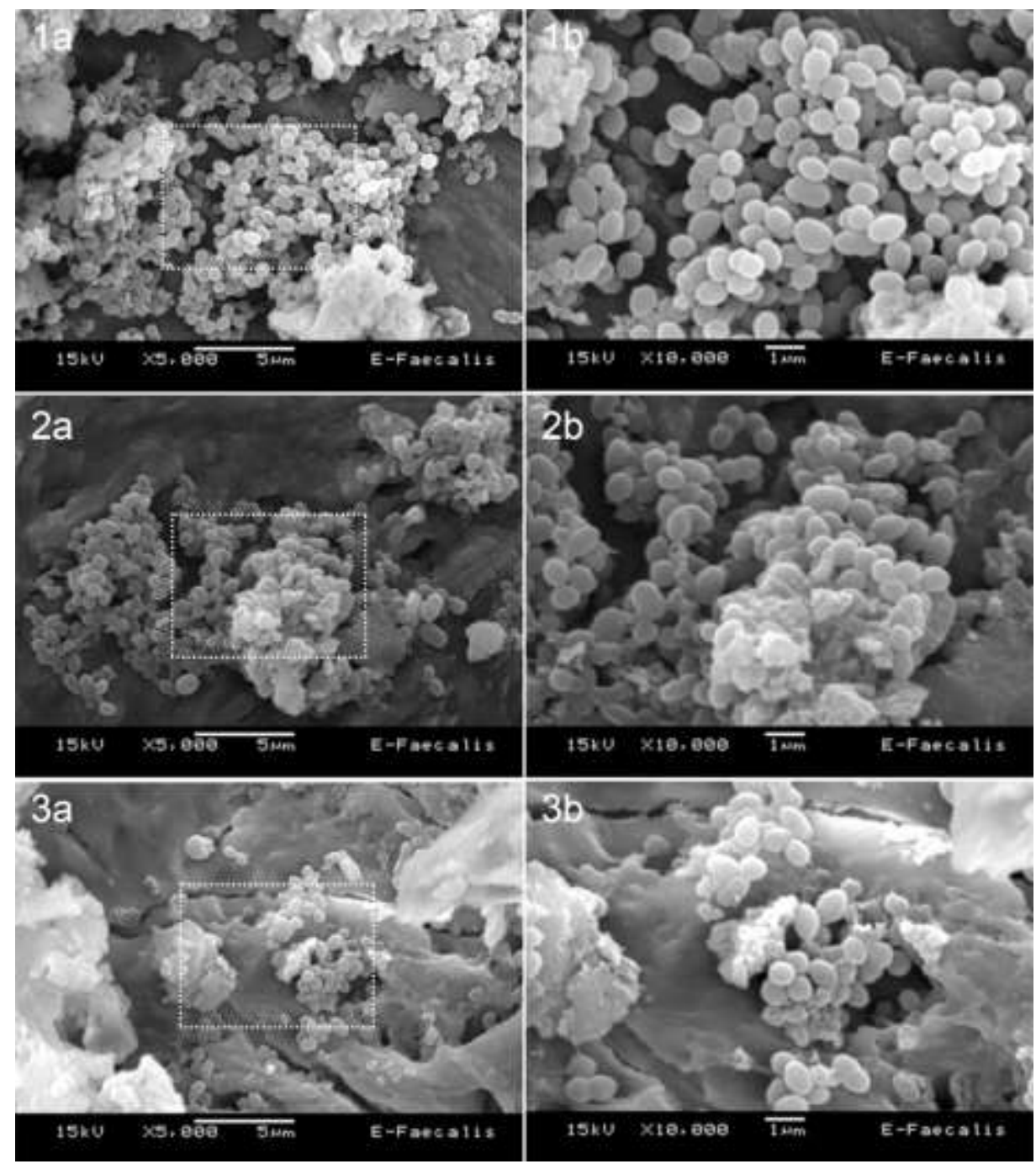

Source: Authors.

Table 1 summarizes the bacterial counts in the test groups at S1 and S2. Comparable bacterial counts were observed in the test groups at baseline (S1) $(p>0.05)$. Bacterial counts were significantly reduced in all groups after root canal treatment (S2) compared to baseline values (S1) $(p<0.001)$. There was no significant difference in bacterial reduction between groups at S2 $(p=0.247)$. Regarding the percentage of bacterial reduction, no significant difference was observed between groups $(p=$ $0.075)$.

Table 1. Mean ( \pm standard deviation) of CFU $/ \mathrm{mL}\left(\times 10^{5}\right)$ in the different groups before (S1) and after (S2) root canal treatment:

\begin{tabular}{lcccc}
\hline Groups & S1 & S2 & $\boldsymbol{p}^{* *}$ & Bacterial reduction (\%) \\
\hline ProDesign Logic 25.03 & $20.32( \pm 18.58)$ & $0.78( \pm 1.09)$ & 0.001 & $96.16 \%$ \\
\hline ProDesign Logic 25.04 & $27.78( \pm 21.90)$ & $1.62( \pm 2.07)$ & 0.001 & $94.17 \%$ \\
\hline ProDesign Logic 25.06 & $37.72( \pm 19.93)$ & $0.88( \pm 1.04)$ & $<0.001$ & $97.64 \%$ \\
\hline $\boldsymbol{p}^{*}$ & 0.072 & 0.247 & - & 0.075 \\
\hline
\end{tabular}

$p^{*}$ : comparison between groups. $p^{* *}$ : comparison between $\mathrm{S} 1$ and $\mathrm{S} 2$ within each group. Source: Authors. 


\section{Discussion}

Endodontic treatment outcomes depend directly on the effective control of intracanal infection. Both root canal irrigation and shaping play crucial roles in reducing bacterial counts to levels compatible with periradicular tissue repair (Ricucci \& Siqueira, 2010). This ex vivo study evaluated the impact of root canal preparation with different file tapers on planktonic and bacterial biofilm reduction (disinfection) in flattened root canals of mandibular incisors.

Sterile saline solution was the only irrigant used in the present study so that the results could be attributed exclusively to the mechanical preparation achieved by different tapers of a single-file endodontic system (Machado, et al., 2010). This protocol has also been used in previous studies (Carvalho, et al., 2019; Tüfenkçi \& Y1lmaz, 2020) with the aim to isolate this variable that reflects in the performance of instruments. In contrast, the association with sodium hypochlorite takes the chemical antibacterial effect of this substance into consideration on the performance of endodontic instruments (Nakamura, et al., 2013).

In the present study, the bacterial counts in the baseline samples (S1) were similar between groups, showing homogeneity in the contamination of the specimens and that a reliable baseline was achieved for the comparison of file tapers. However, bacteria do not only occur as individual colonies (planktonic bacteria) in the intracanal space, but also as communities attached to the root canal walls and in dentinal tubules, named biofilms (Ricucci \& Siqueira, 2010). For this reason, SEM analysis was used to evaluate bacterial colonization, which clearly showed the presence of a biofilm in each root region in all specimens evaluated. This method has been previously validated for confirmation of tooth contamination (Alves, et al., 2012; Siqueira Junior, et al., 2010). In biofilm form, bacterial cells are embedded within a self-produced extracellular matrix and this complex association exhibits great resistance to most antimicrobials and to the host's defense (Ricucci \& Siqueira, 2010; Siqueira Junior, et al., 2010).

Intragroup quantitative CFU analysis of root canal disinfection showed that root canal preparation with different tapers promoted significant intracanal bacterial reduction, suggesting that files with tapers $0.03,0.04$ or 0.06 can successfully reduce microbial counts, even in flattened anatomies. These results confirm the important role of mechanical preparation in disinfecting root canals (Neves, et al., 2016).

Mechanical instrumentation is particularly effective in disrupting bacterial biofilms (Machado, et al., 2010). In this work, a Hedstroem file was used before final sample collection to disorganize the biofilm and thus disaggregate bacterial cells into the canal lumen. Thus, the bacterial load detected by CFU counting in this study originated from planktonic bacteria and bacteria detached from the biofilm adhered to the root dentin walls (Machado, et al., 2013).

Regarding CFU counting of planktonic and disaggregated biofilm bacteria, no significant difference in root canal disinfection was found between single-file systems with different tapers. There was also no difference in the percentage of bacterial removal ( $p>0.05)$. Therefore, the null hypothesis tested was accepted. This is consistent with previous studies in which, under different conditions, different tapers (0.02-0.06) provided similar bacterial counts (Moshari, et al., 2015; Silva, et al., 2014). The literature shows that root canals need to be enlarged sufficiently to remove debris and to allow adequate irrigation of the apical third (Pérez, et al., 2018; Siqueira Junior, et al., 2018). Therefore, the instruments' tapers may play a minor role in root canal disinfection when an appropriate chemomechanical preparation technique is applied.

One explanation for the lack of a significant difference between the different tapers analyzed may be the anatomical pattern of the flattened teeth used in the experiment. Endodontic files, even those with larger tapers, may touch the same wall areas because the instruments tend to remain in the center of the root canal (Alves, et al., 2012; ElAyouti, et al., 2008). Therefore, increasing the instruments' taper can increase the volume of the root canals but the unprepared areas may remain in the irregular regions (ElAyouti, et al., 2008). This has been demonstrated by microcomputed tomography studies that showed that flattened root canal preparation left a variable portion of the area unprepared, regardless of the technique used (Pérez, et 
al., 18; Siqueira Junior, et al., 2018). Mandibular incisors were selected for this study due to the maximal buccolingual dimensions that may be several times larger than the mesiodistal dimension at different levels of the canal, resulting in a high incidence of anatomic irregularities such as fins (Siqueira Junior, et al., 2010; Siqueira Junior, et al., 2018).

A ratio of 2.5:1 between the buccolingual and mesiodistal dimensions was used for the definition of a flattened root canal because the horizontal dimension varies greatly at each vertical level of the canal. These dimensions were measured in the apical, middle and cervical thirds using a digital sliding ruler with a precision of $0.1 \mathrm{~mm}$ (Dental Master DICOM-Plus 1.0.12; Micro Imagem, Indaiatuba, SP, Brazil).

Enterococcus faecalis was the microorganism selected for this study due to its clinical relevance and its prevalence in cases of endodontic failure and persistent apical lesions (Alves, et al., 2012; Ricucci \& Siqueira, 2010; Siqueira Junior, et al., 2010). This species is a facultative gram-positive anaerobic bacterium that presents resistance to survive in adverse conditions such as an alkaline environment for long periods (Molander \& Dahlén, 2003). Enterococcus faecalis also has the ability to penetrate deeply into the dentinal tubules and to produce biofilms on the dentinal surface (Alves, et al., 2012, Siqueira Junior, et al., 2010).

Counting CFU in culture is the most common method used in the literature to evaluate the bacterial reduction produced by endodontic instruments (Alves, et al., 2012). This method was used in this study because it has demonstrated reliable results for the evaluation of intracanal bacterial reduction using different preparation protocols when compared to quantitative real-time polymerase chain reaction (qPCR) (Alves, et al., 2012). Additionally, the CFU method can be used for comparison with previous studies that also evaluated the performance of endodontic instruments in microbial removal (Alves, et al., 2012; Machado, et al., 2013). However, this method has limitations such as the fact that it does not consider low bacterial counts and only detects cultured microorganisms (Rôças, et al., 2004). These limitations could be overcome by the use of molecular methods which, however, may also exhibit some drawbacks. For instance, qPCR detects non-viable microorganisms, a fact that may lead to misinterpretation of the results (Siqueira \& Rôças, 2004).

\section{Conclusion}

Preparation of flattened root canals using ProDesign Logic instruments with tapers of 0.03, 0.04 and 0.06 resulted in similar planktonic and bacterial biofilm reduction. None of the instruments rendered root canals completely free of bacteria.

\section{References}

Alcalde, M. P. , Duarte, M. A. H., Bramante, C. M., et al. (2018). Torsional Fatigue Resistance of Pathfinding Instruments Manufactured from Several NickelTitanium Alloys. International Endodontic Journal, 51, 697-704.

Alves, F. R. F., Rôças, I. N., Almeida, B. M., et al. (2012). Quantitative Molecular and Culture Analyses of Bacterial Elimination in Oval-Shaped Root Canals by a Single-File Instrumentation Technique. International Endodontic Journal, 45, 871-877.

Azim, A. A., Wang, H. H., Tarrosh, M., Azim, K. A., \& Piasecki, L. (2018a). Comparison between Single-File Rotary Systems: Part 1-Efficiency, Effectiveness, and Adverse Effects in Endodontic Retreatment. Journal of Endodontics, 44, 1720-1724.

Azim, A. A., Tarrosh, M., Azim, K. A., \& Piasecki, L. (2018b). Comparison between Single-File Rotary Systems: Part 2-The Effect of Length of the Instrument Subjected to Cyclic Loading on Cyclic Fatigue Resistance. Journal of Endodontics, 44, 1837-1842.

Bürklein, S. \& Schäfer, E. (2015). Minimally Invasive Endodontics. Quintessence International, 46, 119-124.

Carvalho M. C., Zuolo M. L., Arruda-Vasconcelos R., et al. (2019). Effectiveness of XP-Endo Finisher in the Reduction of Bacterial Load in Oval-Shaped Root Canals. Brazilian Oral Research, 33, 1-8.

ElAyouti, A., Chu, A-L., Kimionis, I., et al. (2008). Efficacy of Rotary Instruments with Greater Taper in Preparing Oval Root Canals. International Endodontic Journal, 41, 1088-1092.

Machado, M. E. D. L, Bichels Sapia, L. A., Cai S., Rosa Martins, G. H., \& Nabeshima, C. K. (2010). Comparison of Two Rotary Systems in Root Canal Preparation Regarding Disinfection. Journal of Endodontics, 36, 1238-1240. 
Machado, M. E. L., Nabeshima, C. K., Leonardo, M. F. P., et al. (2013). Influence of Reciprocating Single-File and Rotary Instrumentation on Bacterial Reduction on Infected Root Canals. International Endodontic Journal, 46, 1083-1087.

Molander, A. \& Dahlén, G. (2003). Evaluation of the Antibacterial Potential of Tetracycline or Erythromycin Mixed with Calcium Hydroxide as Intracanal Dressing against Enterococcus Faecalis in Vivo. Oral Surgery, Oral Medicine, Oral Pathology, Oral Radiology, and Endodontics, 96, 744-750.

Moshari, A., Akhlaghi, N., Rahimifard, N., \& Darmiani, S. (2015). Reduction of Enterococcus Faecalis in Curved Root Canals after Various Sizes and Tapers of Canal Preparation. Journal of Conservative Dentistry, 18, 306-309.

Nakamura, V. C., Cai S., Candeiro G. T. M., et al. (2013). Ex Vivo Evaluation of the Effects of Several Root Canal Preparation Techniques and Irrigation Regimens on a Mixed Microbial Infection. International Endodontic Journal, 46, 217-224.

Neves, M. A. S., Provenzano, J. C., Rôças, I. N., \& Siqueira, J. F. (2016). Clinical Antibacterial Effectiveness of Root Canal Preparation with Reciprocating Single-Instrument or Continuously Rotating Multi-Instrument Systems. Journal of Endodontics, 42, 25-29.

Paraskevopoulou, M. T. \& Khabbaz, M. G. (2016). Influence of Taper of Root Canal Shape on the Intracanal Bacterial Reduction. The Open Dentistry Journal, 10, 568-574.

Pérez, A. R., Alves, F. R. F., Marceliano-Alves, M. F., et al. (2018). Effects of Increased Apical Enlargement on the Amount of Unprepared Areas and Coronal Dentine Removal: A Micro-Computed Tomography Study. International Endodontic Journal, 51, 684-690.

Pérez Alejandro, R., Ricucci, D., Vieira, G. C. S., et al. (2020). Cleaning, Shaping, and Disinfecting Abilities of 2 Instrument Systems as Evaluated by a Correlative Micro-Computed Tomographic and Histobacteriologic Approach. Journal of Endodontics, 46, 846-857.

Pinto, J. C., Torres, F. F. E., Santos Junior, A. O., et al. (2021). Influence of Voxel Size on Micro-CT Analysis of Debris after Root Canal Preparation. Brazilian Oral Research, 35(13), 35:e08.

Ricucci, D. \& Siqueira, J. F. (2010). Biofilms and Apical Periodontitis: Study of Prevalence and Association with Clinical and Histopathologic Findings. Journal of Endodontics, 36, 1277-1288.

Rôças, I., Siqueira, J., Santos, K. (2004). Association of Enterococcus Faecalis with Different Forms of Periradicular. Journal of Endodontics, 30, $315-320$.

Silva, E. J. N. L., Nejaim, Y., Silva, A. I. V., et al. (2014). Evaluation of Root Canal Configuration of Maxillary Molars in a Brazilian Population Using ConeBeam Computed Tomographic Imaging: An in Vivo Study. Journal of Endodontics, 40, 173-176.

Siqueira, J. F., Alves, F. R. F., Almeida, B. M., Machado de Oliveira, J. C., Rôças, I. N. (2010). Ability of Chemomechanical Preparation with Either Rotary Instruments or Self-Adjusting File to Disinfect Oval-Shaped Root Canals. Journal of Endodontics, 36, 1860-1865.

Siqueira, J. F. \& Rôças, I. N. (2004). Polymerase Chain Reaction-Based Analysis of Microorganisms Associated with Failed Endodontic Treatment. Oral Surgery, Oral Medicine, Oral Pathology, Oral Radiology, and Endodontics, 97, 85-94.

Siqueira, Junior J. F., Rôças, I. N., Marceliano-Alves, M. F., Pérez, A. R., \& Ricucci, D. (2018). Unprepared Root Canal Surface Areas: Causes, Clinical Implications, and Therapeutic Strategies. Brazilian Oral Research, 32, 1-19.

Tay, F. R., Gu, L. sha., Schoeffel, G. J., et al. (2010). Effect of Vapor Lock on Root Canal Debridement by Using a Side-Vented Needle for Positive-Pressure Irrigant Delivery. Journal of Endodontics, 36, 745-750.

Tüfenkçi, P. \& Yılmaz, K. (2020). The Effects of Different Endodontic Access Cavity Design and Using XP-Endo Finisher on the Reduction of Enterococcus Faecalis in the Root Canal System. Journal of Endodontics, 46, 419-424. 